\title{
Confronting Race and Colonialism: Experiences and Lessons Learned From Teaching Social Studies
}

Bryan Smith

\section{University of Ottawa}

\begin{abstract}
Literature on teacher education and encounters with race highlight some of the difficulties that teacher candidates face when they confront their own racialized subjectivities. However, many of these projects focus exclusively on Whiteness studies, explicating how White teacher candidates come to witness their own racialized Whiteness in relation to their epistemological understandings of the world. In this paper, I diverge from this pattern of thought, exploring a subset of the tenets of critical race theory, that of silences and exclusions, pervading my own teaching in a primary/junior social studies methods class and exploring how these structured my lessons. Specifically, I look at how counternarratives, critiques against liberalism, and multiculturalism and encounters with racialized and colonial supremacy were involved in my pedagogical strategies. I conclude by suggesting that although these methods may seem daunting for the primary/junior classroom, they can provide valuable insights for teacher candidate orientations to their own pedagogies.
\end{abstract}

Keywords: social studies pedagogy; anti-racism in practice 


\section{Confronting Race and Colonialism: Experiences and Lessons Learned From Teaching Social Studies}

As a subject area preoccupied, in part, with the preparation of active citizens in a world desperately in need of contention and social justice, social studies has come to take on quite the pedagogical burden. Curricular documents articulate this burden through rather grandiose definitions meant to distill this complex task into something tangible and pragmatic for teachers in the classroom. This leads to some confusion over the purpose of social studies - it becomes a subject without a definition, or, at best, one with a definition that is subject to constant critique (see Case \& Abbott, 2008, 2013; Johnson, 2006; Maxim, 2003; Wright, 2005). This proves to be a difficult challenge for social studies educators in teacher education programs when broaching the subject on the first day. How one goes about articulating the essence of social studies frames the direction of the course. A common thread through this dialogue about disciplinary essence, however, is the need to engage students in thinking of a better world and their role in precipitating the change necessary to achieve this conceptualization. Within the dominant multicultural framework that shapes most understandings of social studies in Canada, cultural and racial injustices are some of the foci of investigation for students. For example, the province of Ontario's social studies curriculum ${ }^{3}$ includes an antidiscrimination section, which makes clear that, "students...learn that protecting human rights and taking a stand against racism and other expressions of hatred and discrimination are essential components of responsible citizenship" (Ministry of Education, 2004, p. 17).

What follows is a textured reflection on teaching social studies methods in a racialized world through a critical race lens. In so doing, I reflect back on my experiences as a social studies educator (primary/junior) in a teacher education program in Ontario, highlighting the ways in which a critical race lens can help to enrich and/or foster a more critically informed and anti-racist social studies curriculum. Through this, I hope to accomplish two things. First, I wish to theorize and illustrate ways in which various tenets of anti-racism and critical race theory in particular can be easily integrated into social studies programs. Second, I suggest that social studies methods courses in our teacher education programs are desperately in need of an antiracist orientation to address rather taken-for-granted and racialized subject matter in social studies, including nationalist histories (see Stanley, 1998, 2000) and conceptions of Canada as possessing some sort of uncritical benevolence or innocence (Schick \& St. Denis, 2005).

\section{Method}

To increase understanding of how critical race theory might augment social studies education for primary/junior students, I engage in a practice of self-reflection, textured by the principles of critical race theory. Following Larrivee's (2000) critically reflective paradigm for understanding teaching practice, I think back on those moments of self-reflection, how I engaged problem solving in my pedagogy and perhaps most importantly, how I questioned both the student teacher's understandings of the status quo and my own. This model reflects not only the process of knowledge generation for my own pedagogical practice but also highlights the process undertaken in the classroom through my pedagogy and the work of the teacher candidates. Through this, we discussed silences, exclusions, and the ways in which social studies encounters and reflects back on the subjectivity of each learner (both teacher and future students). What follows then is the articulation of insights gleaned from my encounter with my own pedagogy as I work through my understandings of what it means to be a critically reflective, perpetually 
questioning, and persistently self-reflective educator. Consequently, this process follows my (Smith, 2013) suggestion of texturing personal reflection with critical insights to preclude the potential for self-indulgent reflective practice.

\section{Critical Race Framework}

What follows is perhaps a bit ironic in light of my intentions. In seeking to outline a critical race framework as a template for social studies learning, there is a certain irony in using a framework that itself is not universally agreed upon (Delgado \& Stefancic, 2012, p. 7). However, ambiguity and disagreement are always going to persist and the following tenets are generally regarded as consistent across conceptualizations of critical race theory.

\section{Counternarratives, Social Studies, and the Constructed World}

Perhaps the lynchpin of critical race theory (methodologically) is the use of the counternarrative or counterstory to challenge historical and cultural interpretations of reality that reinforce dominant logics and ontologies (Delgado, 1989; Delgado \& Stefancic, 2012; Gillborn, 2006; Gillborn \& Ladson-Billings, 2010; Ladson-Billings, 1998; Solórzano \& Yosso, 2002; Writer, 2008). As a response to taken-for-granted notions of social existence, counternarratives present intrinsically divergent views of racialized relations in the social and ideological space in question. While a central dynamic of critical race theory, the privileging of non-dominant and perhaps subversive narratives from liminal spaces is central to anti-racism as a whole (Dei, 2000; Stanley, 2000), which emphasizes their salience in the critical anti-racist project. The call for recognition of stories that counter hegemonic understandings of the inhabited social landscape are by no means new either-stories, as tools through which to engage epistemological understandings of the social and historical milieu are central to Aboriginal practices of knowledge reproduction (Dion, 2004, 2009). Indeed, the import of orality to Aboriginal narrations of life and the world (Haig-Brown, 2003) warrants an investigation into how oral traditions are relevant to a critical race conceptualization of decolonization. It is perhaps for this reason that, with modifications to account for the colonial dynamic of Aboriginal existence in a state of dominance, critical race theory has been taken up to contend hegemonic understandings of racialized existence by Indigenous scholars (Brayboy, 2005; Writer, 2008).

The idea of counternarratives is something that, at once, is a precarious and exciting avenue for engaging with social studies objectives. The introduction of counternarratives, as Gillborn (2006) suggests, can be used, "in ways that turn dominant assumptions on their head... [and used] to build a powerful challenge to 'mainstream' assumptions" (p. 24). This method of social narrativization then requires a particular comfort in encountering potentially jarring notions of reality. Take for instance Aboriginal history in Canada, a common curricular exploration in schools across the country. Research suggests that representations of traumatic events such as residential schooling are notably absent from or sanitized in history textbooks (Smith, Ng-A-Fook, Berry, \& Spence, 2011). Although just one facet of a rather rich and complex history, similar silencing and sanitization of all such events might explain why, "students [became] visibly anxious when [asked] to consider the possibility of incorporating Aboriginal history in their classroom teachings” (p. 358), as Mishra Tarc (2011), among other scholars, observe. The visible anxiety is but one response of the many that comprise the gamut of emotional responses in the racialized White toolbox. As Lund and Carr (2010) observe about responses to their exploration of Whiteness, resistance to confronting one's White racialized 
subjectivity can sometimes be discursively violent. Indeed, these types of responses to the voices of those who occupy liminal spots beyond the ostensibly deracialized centre come from a vantage point of privilege, one that fails to see and ultimately obscures the stories beyond their own.

Encounters with these counternarratives also require individuals to involve themselves in the production of these stories. My racialized Whiteness, combined with my middle class and masculine subjectivity suggest (and rightly so) that my life narrative is one congruent with dominant narratives of the inhabited national, social, and cultural space. White supremacy ensures this, structuring a process of racialized dominance that elides these narratives from the official ideological record. This exclusion ultimately creates the conditions for these counternarratives as a response and as someone who is committed to an anti-racism project, I am obligated to look at the ways in which my supremacy has silenced and forced racialized nonWhite groups to create their own counternarratives.

Thinking about the pedagogical context, I remind myself of the obligations that educators have to strengthen the value of counternarratives as a response to taken for granted notions of reality. This is not to suggest that dominant narratives should themselves be erased from the record of public consciousness. As Solórzano and Yosso (2002) note, counternarratives, "can teach others that by combining elements from both the story and the current reality, one can construct another world that is richer than either the story or the reality alone” (p. 36). In my own teaching practice with teacher education students, I was obligated to teach the Ontario curriculum, which required that students learn about early settlements, medieval times, and early civilizations. My commitments as an anti-racist educator compelled me to oblige students to consider the voices that were not being heard, those stories of history that provide different experiences. Specifically, in a lesson on the methods of historical thinking (Lévesque, 2008; Seixas, 2006; Seixas \& Morton, 2013), I used primary sources that looked at Aboriginal communities and individuals as a means of getting them to construct and listen to the stories of Aboriginal groups with whom they may have otherwise been unfamiliar. Complementing this was a concerted effort to implore students to recognize the colonial dynamic of Canada's history and to think of Aboriginal groups as having more to offer "than anthropological 'culture' in its limited sense of concrete objects like beads, buffalo, and bannock” (Battiste, 1998, p. 22). The consequence of such imposition was the call for teacher candidates (and me by implication) to listen to those stories that do not get heard.

\section{Liberalism and Coming Face-to-Face With Multiculturalism}

Two major obstructions in teaching social studies are the tropes of multiculturalism and, its complement, tolerance. Many of the student teachers come into the class with rather limited notions of what culture means, which is itself a reflection of a myopic and superficial multicultural discourse in schools that has managed to command an unassailable sacrosanct status. Buttressing this hegemony is a language around "best intentions," which suggests that multiculturalism, as a framework that has the best of intentions is unworthy of legitimate censure. Critical race theory contends these rather problematic notions of tolerance and best intentions and the ways in which these conceal and leave these notions free from critique.

As Gillborn and Ladson-Billings (2010) suggest, a critique of liberalism is central to the critical race project. The reason for such a critique is rather obvious in light of research, which 
suggests that liberalism exists amidst a discursive system as a means of ignoring patterns of racism. For some scholars (Henry \& Tator, 1994, 2002, 2006; Henry, Tator, Mattis, \& Rees, 2009), vehement liberalism is a rather permanent fixture of a democratically justified racism. As Henry et al. (2009) note, democratic liberalism is defined, in part, by "the power of (one) truth, tradition, and history” and those pushing for reconceptualizations, or counternarrative responses, "are seen to be violating a sacred body of principles, values, and beliefs" (p. 117). Such sacred values and beliefs are, upon closer inspection, generally rooted in European traditions and histories inherited through cultural ties back to the "colonial homeland." These values are also highly individualistic, facilitating a process through which fault can be ascribed to the individual and never to the egalitarian liberal system in which they find themselves. As Delgado and Stefancic (2012) put it, liberals vouch for the principle of equality for all, "regardless of their different histories or current situations” (p. 26). Consequently, liberalism is rather blind to historical and contemporary process of domination and hegemonic representations of social conditions.

Pedagogically, the established liberal motif is a difficult one to overcome for two distinct reasons. First, as noted earlier, it is tied to notions of multiculturalism that have attained a nearly inviolable position as the explanatory framework through which to teach diversity and cultural plurality. An example of this can be seen in Ontario. In the early 1990s, the Ministry of Education (1993) released its Antiracism and Ethnocultural Equity in School Boards: Guidelines for Policy Development and Implementation document outlining the Ministry's commitment to anti-racism. The current policy on inclusion, the Realizing the Promise of Diversity: Ontario's Equity and Inclusive Education Strategy (Ministry of Education, 2009) document, engages in a cursory look at the implications of race in the classroom in favour of common liberal tropes such as "diversity." In some ways, this might appear to be a compromise between the NDP's staunch support of anti-racism policies in the 1990s (Gidney, 1999) and the neoconservative and racialized White supremacist views of the succeeding Harris government (Pinto, 2012), reflecting a more palatable political rhetoric that appeases everyone. However, such "middle grounding" locates discussions of race in an unproductive (superficially multicultural) site that elides critical discussions of dominance.

Pedagogically, liberal notions of rights and responsibilities permeate curricula. In my own practices teaching primary/junior social studies, I had to educate teacher candidates on strategies for teaching these tropes since they are explicitly outlined in the curriculum. For example, Grade 1 includes requirements to learn about rules and responsibilities and in Grade 5, students learn about the inner workings of government and citizenship. ${ }^{2}$ The language of liberal rights and responsibilities even inhabits the rather limited antidiscrimination section: "Students are expected to demonstrate an understanding of the rights, privileges, and responsibilities of citizenship, as well as willingness to show respect, tolerance, and understanding towards individuals, groups, and cultures” (Ministry of Education, 2004, p. 17). Consequently, the one section that might provide a space for challenging what critical race theorists note as the normalcy of racism (Gillborn, 2006; Gillborn \& Ladson-Billings, 2010; Ladson-Billing, 1998) fails to do so. More specifically, the language of the antidiscrimination section is deeply problematic. Tolerance implies cultural/racial incongruence and, consequently, the presence of these groups and cultures needs to be endured. Building understanding, while certainly important to offset the exclusionary histories and geographies endemic to social studies, is only effective if the foundational discourses of racialized dominance and colonialism are contended. In other 
words, knowing something about Aboriginal peoples is important, but if we do not confront, with our students, the reasons why these knowledges are excluded, Aboriginal peoples will continue to be marginalized.

In the classroom itself, this contestation of the liberal enterprise was perhaps most challenging in the lessons on citizenship. In my lessons, I approached citizenship from two different angles. The first addressed the pedagogical obligations, providing strategies for teaching about rights, responsibilities, government, and the tools that might be helpful in creating exciting and engaging lessons. The primary focus, however, was on what I called "citizenship as a value," something that echoes the work and postulations of critical citizenship literature (see Clark, 2008, 2013; Ponder \& Lewis-Ferrell, 2009; Westheimer \& Kahne, 2004). In this model, I encourage students to think beyond citizenship as simplistic engagements with volunteering and personal values such as honesty and adherence to the law. In so doing, I have found that I struggle to press home the point that citizenship could and should be about not just enacting change but also about developing the habits of mind to know how and when to ask critical questions. I do not fault my students for a rather initially myopic conceptualization of citizenship, just as I would not fault students individually for reflecting back White supremacist notions of racialized relationships. Much like Marx and Pennington (2003), I feel it is vital to "tolerate their biased beliefs and attitudes in the initial stages of our conversations," while concurrently recognizing that I am, "influenced by and affected by Whiteness and White racism just as much as [the] students/participants” (p. 94). Instead, I raise this to reflect what appears to be an endemic problem. In our social studies teacher education programs, relations of racialized dominance are negated by an ideology of liberalism that conspires with multiculturalism to create a representation of reality that makes racism abhorrent, instead of normal. In these lessons with students, imploring them to think of citizenship projects that might question relations of dominance were often met with conceptions of citizenship that leaned heavily on liberal motifs of "change."

\section{White Supremacy and the Challenge of Narrative Record}

Following from the notion that racism is not an abhorrent act of discrimination but a pervasive and normative condition of social and political relations, critical race theorists argue that White supremacy structures the lives of racialized bodies in the social milieu. Historically, it has shaped and regulated the lives of racialized non-White groups including, but not limited to, Indigenous peoples in colonial states (Brayboy, 2005) and Chinese people in Canada (Stanley, 2011). In the contemporary context, White supremacy still very much exists as a structuring ideology but does so in much more banal and muted ways in everyday interactions. Despite this, its presence lingers, structuring the essence of the everyday, eliding the narratives of racialization by co-opting these ideas for the validation of such dominance. For example, Stanley's (2009) tour of Vancouver highlights the banality of colonial markers and the ways in which such adornments are symbolically absorbed into the public consciousness in unquestioned ways. This supremacy though extends beyond the symbolic, organizing the ways in which the world as we know it is filtered through a racialized White tinted epistemological and ontological lens. An example of this is the grand narrative of history, a common (and sometimes sole) historical record used in pedagogical practice. Such histories valorize racialized White contributions such that a, "white imprint is everywhere" unless the representations are negative (Leonardo, 2004, p. 149) in which case Whiteness is juxtaposed with something problematic. Whiteness's indelibility is, therefore, limited to that which casts a positive light on its presence. 
The banality of such racialized dominance is central to critical race conceptions of social and political existence. Critical race scholars centre this notion of White supremacy (Gillborn, 2005) as an attempt to emphasize what was said earlier - supremacy is an everyday practice, not one that reflects jarring and nefarious practices designed to enact overt acts of physical, emotional, and psychological violence. In this way, critical race theorists highlight the ways in which such supremacy enacts a more nuanced and subtle form of violence that appears to be a myth. Such a process can be thought of as similar to the popular anecdote about the boiled frog. The fallacious anecdote suggests that, placed in boiling water, a frog will quickly jump out for its own safety. However, if it is placed in cold water that is then boiled, the frog will be unaware of the temperature changes and, thus, will not attempt to escape what is an inevitable death. Notions of White supremacy follow a similar metaphorical template. Traditional notions are akin to the "frog placed into boiling water" in that, when made aware of abhorrent practices of racial dominance, people will quickly extricate themselves from the context. White supremacy is more like the slowly boiling pot in that we exist in a context that slowly and imperceptively produces conditions that are detrimental to those within the "pot" that is the social milieu. Racialized White people are commonly unable to see the slowly boiling water that is the relations of supremacy that they depend on which makes palatable what might otherwise be perceived as disgraceful.

The enactment and reflection of Whiteness, White supremacy and privilege, "the daily cognate of structural domination” (Leonardo, 2004, p. 148), is a well-documented phenomenon in teacher education programs (Levine-Rasky, 2000; Picower, 2009; Solomon, Portelli, Daniel, \& Campbell, 2005). Although not a social foundations course (one that teacher candidates come to largely expect as the realm in which supremacy might be taken up), my social studies course attempted to disrupt the dominance of Whiteness. Although I did not address the personal engagements with and responses to Whiteness (guilt, anger, etc.), I did work to interrupt their understandings of how Whiteness offers itself as the taken-for-granted way of understanding the world. In my second week, I began with questions of historical significance, one of the primary methods of historical thinking (Lévesque, 2008; Seixas, 2006; Seixas \& Morton, 2013). Common perceptions around significance are highly racialized, focusing on nationalist accomplishments which, as part of the grand narrative of history, have, in Stanley's (2000) words, "ceased to be [part of] a story about the past, but has come to be the past itself" (p. 82). Much like the entrenched liberalism indelibly marked into perceptions of rights and justice, I do not fault the students for articulating significance in relation to the grand narrative of national progress. Instead, I implore students to re-engage with a narrative that is perceived to have been settled, $^{3}$ asking them to consider what might be significant for those who are generally absent from the common narrative of national history.

Although scholars such as Newhouse (2005) do argue that, "in a post-modern age, the idea of one grand narrative is losing ground" (p. 49), the continued centralization of European narrativization suggests that White supremacy's command of ontological truth continues unabated. In challenging the explanatory power of this narrative, I explored how notions of colonialism in the nation-state could destabilize the preconceptions of the teacher candidates. Although colonialism may not have been a suitable topic for some of the grades that these teacher candidates may teach, having them question how colonialism has shaped our understanding provided them with the critical mindset to question their presuppositions of racialized white dominance. Specifically, in discussing global education, I encouraged teacher 
candidates to read news sources from around the world not only to broaden their understandings but also to get them to think about how they could do a media literacy task using news sources from different places. In this lesson, I showed the students a copy of an Al Jazeera opinion piece on the Idle No More movement and its fight against the racialized White colonial supremacy of the nation-state. The article was titled “'Idle No More' and Colonial Canada” and its first line states the following: "Canada's colonial reality is now in the spotlight, as Idle No More protests voice the struggles of indigenous people against sustained political and economic oppression" (Christoff, 2013). I asked students what they saw here that they would likely never see in an article from a Canadian news outlet. They were quick to note the use of the adjective "colonial" and the ways in which it was used to describe the state's relationship to the Aboriginal communities of the land. In part, this augmented a previous lesson discussing why some unknown individuals might have defaced a statue of Sir John A. MacDonald with the words murderer and colonizer.

Although short lessons such as these do not contend the daily set of privileges and acts of supremacy that inhere in the social fabric of the racialized nation, they do provoke the teacher candidates to consider patterns of dominance and the unheard voices who are subjected to said dominance. They also provide opportunity for our student teachers to consider what they might not know and to think about how the silences and sanitized representations in the curricular materials they use (Smith et al., 2011), and used themselves as students, might have been a reflection of a supremacy that reinforced relations of dominance. Recognizing the supremacy is the first important step in unraveling the tapestry of meanings that texture the racialized supremacy of everyday life.

\section{Anti-Racist/Decolonizing Tensions: A Comment}

The preceding discussion includes calls for decolonization to accompany anti-racist engagement with social studies pedagogy. While anti-racist scholarship calls for decolonization as a central tenet of its important work (see, for example, Stanley, 2000), conflation of the two concepts can be dangerous given the important discursive, historic, and cultural consequences of colonialism in relation to other forms of racialized dominance. Without a recognition of the nuanced ways in which colonialism operates in relation to other forms of racism, one risks creating a colonizing anti-racism. Indeed, Lawrence and Dua (2005) express caution about the ways in which colonization is excluded from anti-racism work. This lack of specific attention to the details of colonialism appears in Brayboy's (2005) articulation of “tribal CRT”:

While CRT serves as a framework in and of itself, it does not address the specific needs of tribal peoples because it does not address American Indians' liminality as both legal/political and racialized beings or the experience of colonization. (pp. 428-429)

This is not to suggest that the two frameworks cannot be enmeshed successfully-Tupper and Cappello (2008) apply critical race theory tenets to treaty education (a project designed to attend to colonial histories) and do so, successfully. However, the specificities of the colonial condition, both historic and contemporary, require an attunement to the distinctions between racism that is informed and structured by colonialism and that which is not. The project of colonialism has produced very different results for Aboriginal peoples both in terms of their representation in the politics and culture of Canada and in their presence (or lack thereof) in pedagogical texts (see Smith et al., 2011). 
This is not to suggest that colonialism and anti-racism are mutually exclusive or should be understood as such. As noted, they are very much entangled. However, as Lawrence and Dua (2005) argue, it is possible for anti-racism to be exclusive of decolonizing work. That said, antiracist work, if operating blind to colonialism in Canada, may reify colonial conditions if it fails to see how these patterns of dominance occur on lands appropriated through colonialism's pernicious desire to consume lands, cultures, and histories. An anti-racist theorization of social studies consequently needs to be attuned to the nuances of colonialism in Canada. These antiracist social studies pedagogies must remain cognizant of the nuanced relations that not only inhere in colonial perceptions of the Aboriginal other but also must remain attentive to the specificities of the other racisms being addressed.

One possible entry point into this issue within the classroom space is through a discussion of legal relations. The law has and remains to be a productive and powerful discursive tool to regulate bodies. An excellent example of this is the legislation that has been crafted to control Aboriginal peoples. In Canada, Aboriginal people remain, effectively, wards of the federal state. They are also a group that is subject to legislation designed specifically with the intent to articulate the relationship between themselves and the state (the Indian Act), a legislative condition not shared by other groups in Canada. Asking students to consider why this might be and what the consequences of this might involve is one avenue to disrupt not only multiculturalism as the means through which everyone is ostensibly made equal but also as an introduction to the idea that legal and political frameworks have indelible and persistent consequences. Even asking students to imagine laws designed to regulate other cultural groups, an act that would most likely evoke strong criticisms, can point to the ease with which colonial politics operates.

\section{Conclusion}

The three tenets covered here, although not presenting the complete list of critical race tenets, does illustrate the rather subtle but important ways that critical race theory can imbue a social studies methods course for primary/junior grades. While many of the more difficult topics of race and colonial dominance are perhaps better suited for the upper grades, there is a compelling ethical and moral commitment to planting the seeds of resistance at an early age. Concurrently, it is important to shift the mindsets of primary/junior teacher candidates, imploring them to think beyond myopic understandings of a simplistic world. It is only when teachers see the complexity and myopia of some of their historic, geographic, and political commitments that they can then make such complexity available to their students.

The discussion here, as noted, is not exhaustive. One of the major tenets excluded from this discussion is the notion of "interest convergence" (Bell, 1980; Delgado \& Stefancic, 2012; Gillborn, 2006; Gillborn \& Ladson-Billings, 2010; Ladson-Billings, 1998). This idea suggests that the rights of marginalized groups were and are only furthered when said progress converges with the interests of dominant racialized White groups. In other words, rights and benefits for marginalized groups are only realized when it conveniences and converges with those of racialized Whites. Although a seemingly daunting and controversial topic to broach in a teacher education classroom, the pervasiveness of a rights discourse through curricula (as mentioned earlier) would seem to suggest that this is a thoroughly appropriate topic to address with teacher candidates. Some critical questions to consider might be: "Has such a process occurred in Canada?" "Whose rights were gained and how might this have been a reflection of White 
supremacist interests?" "Did (does) one group in Canada stand to benefit from something because it also benefits the unseen majority?”

There is no perfect model for engaging issues of race in the classroom. The glut of research on Whiteness in teacher education programs alone emphasizes the ongoing complications about encountering race on the part of teacher candidates. However, applying the principles of anti-racism frameworks (such as critical race theory) can offer teacher educators a method of engaging candidates in the troubling issues around race, colonialism, and dominance. I further suggest that these lessons do not have to be explicit and discrete blocks (indeed, to do so would suggest that engaging racism is something you can do in a block) but can and should pervade our lessons. Doing this, however, requires that teacher candidates are aware of their professors' anti-racist intentions — students should not be tricked into being anti-racist educators. The process also needs to focus on both pedagogical lessons for their future students and lessons about their own pre/misconceptions about the world. By empowering the voices of those subject to relations of dominance, by contending the myopia and dangers of complacent liberalism and multiculturalism, and by challenging relations of supremacy, confidence in anti-racism can be fostered that will translate into tangible benefits for future students. 


\section{References}

Battiste, M. (1998). Enabling the autumn seed: Toward a decolonized approach to Aboriginal knowledge, language, and education. Canadian Journal of Native Education, 22(1), 16-27.

Bell, D. A. (1980). Brown v. Board of Education and the interest-convergence dilemma. Harvard Law Review, 93(3), 518-533. Retrieve from http://pscfiles.tamu.edu/links/div-com/bell-interest\%20convergence.pdf

Brayboy, B. M. J. (2005). Toward a tribal critical race theory in education. The Urban Review, 37(5), 425-446.

Case, R., \& Abbott, M. (2008). Purposeful teaching in elementary social studies. In R. Case \& P. Clark (Eds.), The anthology of social studies: Issues and strategies for elementary teachers (Volume 1, pp. 8-17). Vancouver, BC: Pacific Educational Press.

Case, R., \& Abbott, M. (2013). Creating meaningful goals for elementary social studies. In R. Case \& P. Clark (Eds.), The anthology of social studies: Issues and strategies for elementary teachers (Updated., pp. 9-18). Vancouver, BC: Pacific Educational Press.

Christoff, S. (2013). 'Idle No More' and Colonial Canada - Opinion - Al Jazeera English. Retrieved from http://www.keepeek.com/Digital-Asset-Management/oecd/socialissues-migration-health/the-causes-of-growing-inequalities-in-oecdcountries_9789264119536-en

Clark, P. (2008). All talk and no action? The place of social action in elementary social studies. In R. Case \& P. Clark (Eds.), The anthology of social studies: Issues and strategies for elementary teachers (Volume 1, pp. 197-208). Vancouver, BC: Pacific Educational Press.

Clark, P. (2013). Conduction social action in elementary social studies. In R. Case \& P. Clark (Eds.), The anthology of social studies: Issues and strategies for elementary teachers (Updated., pp. 135-147). Vancouver, BC: Pacific Educational Press.

Dei, G. J. S. (2000). Towards an anti-racism discursive framework. In G. J. S. Dei \& A. Calliste (Eds.), Power, knowledge and anti-racism education (pp. 23-39). Halifax, NS: Fernwood Publishing. Retrieved from http://site.ebrary.com/lib/oculottawa/docDetail.action?docID=10192195

Delgado, R. (1989). Storytelling for oppositionists and others: A plea for narrative. Michigan Law Review, 87(8), 2411-2441.

Delgado, R., \& Stefancic, J. (2012). Critical race theory: An introduction (2nd ed.). New York, NY: New York University Press.

Dion, S. D. (2004). (Re)telling to disrupt: Aboriginal people and stories of Canadian history. Journal of the Canadian Association for Curriculum Studies, 2(1), 55-76. 
Dion, S. D. (2009). Braiding histories: Learning from Aboriginal peoples' experiences and perspectives. Vancouver, BC: UBC Press.

Gidney, R. D. (1999). From hope to Harris: The reshaping of Ontario's schools. Toronto, ON: University of Toronto Press Inc.

Gillborn, D. (2005). Education policy as an act of White supremacy: Whiteness, critical race theory and education reform. Journal of Education Policy, 20(4), 485-505.

Gillborn, D. (2006). Citizenship education as placebo: "Standards”, institutional racism and education policy. Education, Citizenship and Social Justice, 1(1), 83-104.

Gillborn, D., \& Ladson-Billings, G. (2010). Education and critical race theory. In M. W. Apple, S. J. Ball, \& L. A. Gandin (Eds.), The Routledge international handbook of the sociology of education (pp. 37-47). New York, NY: Routledge.

Granatstein, J. L. (1998). Who killed Canadian history? Toronto, ON: HarperCollins Publishers.

Haig-Brown, C. (2003). Creating spaces: Testimonio, impossible knowledge, and academe. International Journal of Qualitative Studies in Education, 16(3), 415433.

Henry, F., \& Tator, C. (1994). The ideology of racism: Democratic racism. Canadian Ethnic Studies, 26(2), 1-14.

Henry, F., \& Tator, C. (2002). Discourses of domination: Racial bias in the Canadian English-language press. Toronto, ON: University of Toronto Press.

Henry, F., \& Tator, C. (2006). The colour of democracy: Racism in Canadian society (3rd ed.). Toronto, ON: Thomson Nelson.

Henry, F., Tator, C., Mattis, W., \& Rees, T. (2009). The ideology of racism. In M. Wallis \& A. Fleras (Eds.), The politics of race in Canada: Readings in historical perspectives, contemporary realities, and future possibilities (pp. 108-118). Don Mills, ON: Oxford University Press.

Johnson, A. P. (2006). Making connections in elementary and middle school social studies. Thousand Oaks, CA: Sage Publications, Inc.

Ladson-Billings, G. (1998). 'Just what is critical race theory and what's it doing in a nice field like education?' International Journal of Qualitative Studies in Education, 11(1), 7-24.

Larrivee, B. (2000). Transforming teaching practice: Becoming the critically reflective teacher. Reflective Practice, 1(3), 293-307.

Lawrence, B., \& Dua, E. (2005). Decolonizing antiracism. Social Justice, 32(4), 120 143.

Leonardo, Z. (2004). The color of supremacy: Beyond the discourse of "White privilege." Educational Philosophy and Theory, 36(2), 137-152. 
Lévesque, S. (2008). Thinking historically: Educating students for the twenty-first century. Toronto, ON: University of Toronto Press.

Levine-Rasky, C. (2000). The practice of Whiteness among teacher candidates. International Studies in Sociology of Education, 10(3), 263-284.

Lund, D. E., \& Carr, P. R. (2010). Exposing privilege and racism in the great White North: Tackling Whiteness and identity issues in Canadian education. Multicultural Perspectives, 12(4), 229-234.

Marx, S., \& Pennington, J. (2003). Pedagogies of critical race theory: Experimentations with White preservice teachers. International Journal of Qualitative Studies in Education, 16(1), 91-110.

Maxim, G. W. (2003). Dynamic social studies for elementary classrooms (7th ed.). Upper Saddle River, NJ: Pearson Education, Inc.

McKillop, A. B. (1999). Who killed Canadian history? A view from the trenches. Canadian Historical Review, 80(2), 269-300.

Ministry of Education. (1993). Antiracism and ethnocultural equity in school boards: Guidelines for policy development and implementation. Retrieved from http://www.edu.gov.on.ca/eng/document/curricul/antiraci/antire.pdf

Ministry of Education. (2004). The Ontario curriculum, social studies (Grades 1 to 6), history and geography (Grades 7 and 8). Toronto, ON: Queen’s Printer for Ontario.

Ministry of Education. (2009). Realizing the promise of diversity: Ontario's equity and inclusive education strategy. Retrieved from http://cal2.edu.gov.on.ca/april2009/EquityEducationStrategy.pdf

Ministry of Education. (2013). The Ontario curriculum, social studies (Grades 1 to 6), history and geography (Grades 7 and 8) (Revised). Toronto, ON: Queen’s Printer for Ontario.

Mishra Tarc, A. (2011). Reparative curriculum. Curriculum Inquiry, 41(3), 350-372.

Newhouse, D. (2005). Telling our story. In U. Lischke \& D. McNab (Eds.), Walking a tightrope: Aboriginal people and their representations (pp. 45-52). Waterloo, ON: Wilfrid Laurier University Press.

Picower, B. (2009). The unexamined Whiteness of teaching: How White teachers maintain and enact dominant racial ideologies. Race Ethnicity and Education, 12(2), 197-215.

Pinto, L. E. (2012). Curriculum reform in Ontario: "Common sense” policy processes and democratic possibilities. Toronto, ON: University of Toronto Press.

Ponder, J., \& Lewis-Ferrell, G. (2009). The butterfly effect: The impact of citizenship education. The Social Studies, 100(3), 129-135. 
Schick, C., \& St. Denis, V. (2005). Troubling national discourses in anti-racist curricular planning. Canadian Journal of Education, 28(3), 295-317.

Seixas, P. (2006). Benchmarks of historical thinking: A framework for assessment in Canada (pp. 1-12). Vancouver, BC: Centre for the Study of Historical Consciousness, UBC. Retrieve from http://courses.educ.ubc.ca/cite/socials/Articles/Framework.Benchmarks.pdf

Seixas, P., \& Morton, T. (2013). The big six: Historical thinking benchmarks. Toronto, ON: Nelson Education Ltd.

Smith, B. (2013). Currere and critical pedagogy: Thinking critically about self-reflective methods. Transnational Curriculum Inquiry, 10(2), 3-16.

Smith, B., Ng-A-Fook, N., Berry, S., \& Spence, K. (2011). Deconstructing a curriculum of dominance: Teacher education, colonial frontier logics, and residential schooling. Transnational Curriculum Inquiry, 8(2), 53-70.

Solomon, R. P., Portelli, J. P., Daniel, B.-J., \& Campbell, A. (2005). The discourse of denial: How White teacher candidates construct race, racism and "White privilege.” Race Ethnicity and Education, 8(2), 147-169.

Solórzano, D. G., \& Yosso, T. J. (2002). Critical race methodology: Counter-storytelling as an analytical framework for education research. Qualitative Inquiry, 8(1), 2344.

Stanley, T. J. (1998). The struggle for history: Historical narratives and anti-racist pedagogy. Discourse: Studies in the Cultural Politics of Education, 19(1), 41-52.

Stanley, T. J. (2000). Why I killed Canadian history: Towards an anti-racist history in Canada. Histoire Sociale/Social History, 33(65), 79-103.

Stanley, T. J. (2009). The banality of colonialism: Encountering artifacts of genocide and White supremacy in Vancouver today. In S. R. Steinberg (Ed.), Diversity and multiculturalism: A reader (pp. 143-159). New York, NY: Peter Lang Publishing, Inc.

Stanley, T. J. (2011). Contesting White supremacy: School segregation, anti-racism, and the making of Chinese Canadians. Vancouver, BC: UBC Press.

Tupper, J. A., \& Cappello, M. (2008). Teaching treaties as (un)usual narratives: Disrupting the curricular commonsense. Curriculum Inquiry, 38(5), 559-578.

Westheimer, J., \& Kahne, J. (2004). What kind of citizen? The politics of educating for democracy. American Educational Research Journal, 41(2), 237-269.

Wright, I. (2005). Elementary social studies: A practical approach to teaching and learning (6th ed.). Toronto, ON: Pearson Education Canada.

Writer, J. H. (2008). Unmasking, exposing, and confronting: Critical race theory, tribal critical race theory and multicultural education. International Journal of Multicultural Education, 10(2), 1-15. 


\section{Endnotes}

${ }^{1}$ It is worth noting that between the initial draft of this paper and the final version, the Ontario Ministry of Education (2013) published a revised version of the social studies curriculum. Although the curricular subject areas have changed slightly, the principles and theoretical arguments here still apply to the principles of teaching social studies not only in Ontario but also beyond the province.

${ }^{2}$ As noted, the experiences outlined here were undertaken in relation to the old social studies curriculum in Ontario, which has since been supplanted by the new revised edition (Ministry of Education, 2013). Students in Grade 1 continue to learn about roles and responsibilities and while grade 5 students will still learn about government and citizenship, there is a marked shift in notions of citizenship, one in which citizenship is now largely defined in relation to active involvement in the community.

${ }^{3}$ As Granatstein (1998) argues, the national-political narrative should be the "standard history" and argues this in light of what he sees as a threat to its hegemony. Needless to say, such an argument has elicited various retorts from scholars (see McKillop, 1999; Stanley, 2000). 